\title{
Melanocortin crosstalk with adipose functions: ACTH directly induces insulin resistance, promotes a pro-inflammatory adipokine profile and stimulates UCP-1 in adipocytes
}

\author{
K Alexander H Iwen, Oezge Senyaman*, Arne Schwartz*, Maren Drenckhan, Britta Meier, \\ Dirk Hadaschik and Johannes Klein
}

Department of Internal Medicine I, University of Lübeck, Ratzeburger Allee 160, 23538 Lübeck, Germany

(Correspondence should be addressed to J Klein; Email: j.klein@uni-luebeck.de)

*O Senyaman and A Schwartz contributed equally to this work

\begin{abstract}
The melanocortin (MC) system is a pivotal component of the hypothalamo-pituitary-adrenal (HPA) stress axis and plays an important role in the pathogenesis of obesity and the metabolic syndrome. Adipose dysfunction is implicated in the pathogenesis of these disorders. We investigated direct ACTH effects on adipose functions in immortalised murine white and brown adipocytes. $\mathrm{MC}$ receptor types 2 and 5 were expressed at the mRNA and protein levels and were strongly up-regulated during differentiation. Chronic ACTH stimulation did not affect adipogenesis. Insulin-induced glucose uptake in white adipocytes was acutely and transiently reduced by $45 \%$ upon ACTH treatment. Visfatin and adiponectin gene expression was reduced by about $50 \%$ in response to ACTH, while interleukin-6 (IL-6) and monocyte chemoattractant protein-1 (MCP-1) mRNA levels were acutely up-regulated by 2100 and $60 \%$ respectively. Moreover, IL-6 secretion was
\end{abstract}

increased by $1450 \%$ within $4 \mathrm{~h}$ of ACTH treatment. In brown adipocytes, stimulation with ACTH caused a $690 \%$ increase in uncoupling protein (UCP)-1 mRNA levels within $8 \mathrm{~h}$, followed by a $470 \%$ increase in UCP-1 protein concentrations after $24 \mathrm{~h}$. Consistently, p38 mitogen-activated protein kinase (MAPK) phosphorylation was acutely increased by $1800 \%$ in response to ACTH stimulation, and selective inhibition of p38 MAPK abolished the ACTH-mediated UCP-1 protein increase. Taken together, ACTH acutely promotes an insulinresistant, pro-inflammatory state and transiently enhances energy combustion. In conditions characterised by a dysregulation of the HPA stress axis such as the metabolic syndrome, direct $\mathrm{MC}$ interaction with adipocytes may contribute to dysregulated energy balance, insulin resistance and cardiometabolic complications.

Journal of Endocrinology (2008) 196, 465-472

\section{Introduction}

Obesity and insulin resistance are at the centre of the metabolic syndrome which is a major risk factor for the development of cardiovascular disease. There is growing evidence for an implication of adipose dysfunction critically promoting the development of this syndrome and its complications (Despres \& Lemieux 2006).

The melanocortin (MC) system plays an important role in the regulation of body weight (Butler 2006, Farooqi \& O'Rahilly 2006). Moreover, MCs are also pivotal components of the hypothalamo-pituitary-adrenal (HPA) stress axis, and dysregulation of this axis is associated with human obesity (Pasquali et al. 1993, Vicennati \& Pasquali 2000, Rosmond 2003).

The MC system consists of the agonistic peptides $\alpha, \beta$ and $\gamma$ melanocyte-stimulating hormone (MSH) as well as the adrenocorticotrophic hormone (ACTH) which are cleavage products of pro-opiomelanocortin. MCs bind to and activate five $\mathrm{MC}$ receptor subtypes (MC1 through $5 \mathrm{R}$ ). These seven transmembrane G-protein-coupled receptors are distributed in a species- and tissue-specific manner. Furthermore, the system also includes endogenous MC receptor antagonists, agouti and agouti-related protein (Gantz \& Fong 2003).

Few reports on direct interactions of MCs with adipocytes have been published. Stimulation of 3T3-L1 cells with MCs has been reported to cause an increase in cAMP concentrations (Boston \& Cone 1996, Norman et al. 2003). ACTH and $\alpha \mathrm{MSH}$ inhibit leptin expression and secretion in 3T3-L1 cells and primary rat adipocytes (Norman et al. 2003, Hoggard et al. 2004), and induce lipolysis (Boston 1999).

Given a potential direct implication of MCs in the induction of adipose dysfunction, we examined direct actions of ACTH on key metabolic and endocrine adipose responses in white and brown adipocytes respectively. This study demonstrates a direct ACTH-mediated induction of transient insulin resistance, a pro-inflammatory adipokine profile and 
a p38 mitogen-activated protein kinase (MAPK)-mediated induction of energy combustion.

\section{Materials and Methods}

\section{Materials}

All materials were obtained from Sigma-Aldrich unless stated differently.

\section{Cell culture}

Immortalised murine adipocyte cell lines were cultured and differentiated as previously described (Klein et al. 1999, 2000, 2002, Jost et al. 2002, Kraus et al. 2002, Perwitz et al. 2006). In brief, the cells were grown to confluence on $10-\mathrm{cm}$ culture plates (Sarstedt, Nümbrecht, Germany) in Dulbecco's modified Eagle's medium (Life Technologies) supplemented with $20 \%$ foetal bovine serum, $4.5 \mathrm{~g} / 1$ glucose, $20 \mathrm{nmol} / 1$ insulin and $1 \mathrm{nM}$ tri-iodothyronine ('differentiation medium'). Adipocyte differentiation was induced by complementing the medium further with $250 \mu \mathrm{mol} / 1$ indomethacin, $500 \mu \mathrm{mol} / 1$ isobutylmethylxanthine and $2 \mu \mathrm{g} / \mathrm{ml}$ dexamethasone for $24 \mathrm{~h}$ when confluence was reached. After this period, the cells were changed back to differentiation medium. Cell culture was continued for 5 more days, before cells were serum deprived for $24 \mathrm{~h}$ prior to carrying out the experiments. Differentiated adipocytes were used between passages 15 and 30. The final concentration of ACTH (Bachem, Bubendorf, Switzerland) was $100 \mathrm{nM}$. The p38 MAPK inhibitor SB 202190 (Calbiochem, San Diego, CA, USA) was added $1 \mathrm{~h}$ prior to ACTH treatment of cells at a final concentration of $10 \mu \mathrm{M}$ in the respective experiments.

\section{Immunoblotting}

Cells were lysed using whole cell lysis buffer containing $2 \mathrm{mM}$ vanadate, $10 \mu \mathrm{g} / \mathrm{ml}$ aprotinin, $10 \mu \mathrm{g} / \mathrm{ml}$ leupeptin and $2 \mathrm{mM}$ phenylmethylsulphonyl fluoride. Protein content of the lysates was determined using the Bradford assay according to the manufacturer's instructions (Bio-Rad). Lysates were subjected to SDS-PAGE and transferred to nitrocellulose membranes (Schleicher and Schuell, Keane, NH, USA). The membranes were incubated overnight with rinsing buffer (10 mM Tris, $150 \mathrm{mM} \mathrm{NaCl,} 0 \cdot 05 \%$ Tween, $\mathrm{pH} 7 \cdot 2$ ) containing 3\% BSA ('blocking solution'). Antibodies were added for $1-2 \mathrm{~h}$ in the appropriate dilutions. Protein bands were visualised using a chemiluminescence kit (Roche Molecular Biochemicals). UCP-1 antibody, $\beta$-actin antibody and specific MC receptor antibodies were purchased from Chemicon (Temecula, CA, USA). Phospho-specific and total p38 MAPK antibodies were obtained from Cell Signaling (Beverly, MA, USA). Specific aP2 antibody was purchased from Santa Cruz Biotechnology (Santa Cruz, CA, USA). Densitometry was performed using the programme Quantity One version 4.2.3 (Bio-Rad).

\section{Quantitative real-time reverse transcription PCR}

Quantitative real-time RT-PCR was performed, with 36B4 as a housekeeping gene. Total RNA isolation was carried out using TRIzol reagent (Invitrogen). To optimise RNA quality, clean-up and DNase digestion were performed using the RNeasy kit and RNase-Free DNase Set (Qiagen). Quality of RNA was tested by photometric analysis and agarose gel electrophoresis. Two microgram of total RNA were reverse transcribed using Superscript II (Invitrogen) and oligo p(dT) 15 primers (Roche Molecular Biochemicals) in the presence of RNase inhibitor (Roche Molecular Biochemicals) in a $20 \mu \mathrm{l}$ reaction. One microlitre of each $\mathrm{RT}$ reaction was amplified in a total volume of $25 \mu \mathrm{l}$ containing $1 \times$ QuantiTect SYBR Green PCR-Mix (Qiagen) and $250 \mathrm{nmol} / \mathrm{l}$ of each primer, using the GeneAmp 7000 Sequence Detection System (Applied Biosystems, Foster City, CA, USA). The primer sequences are available on request. 36B4 served as housekeeping gene. Identity of the amplified product was confirmed by melting curve analysis and agarose gel electrophoresis. Optimised relative quantification was done using the Relative Expression Software (Pfaffl et al. 2002).

\section{PCR}

Qualitative PCRs for MC receptors 1 through 5 were carried out in a Cyclon gradient cycler (Peqlab Biotechnologie $\mathrm{GmbH}$, Erlangen, Germany). Three microlitre of the RT reaction were amplified in a total volume of $30 \mu$ containing $10 \times$ Reaction Buffer S (Peqlab Biotechnologie GmbH), $5 \mathrm{U}$ of Taq DNA Polymerase (Peqlab Biotechnologie GmbH), $166 \mathrm{nmol} / \mathrm{l}$ of each primer (Biometra, Göttingen, Germany) and $300 \mu \mathrm{mol} / 1$ of each dNTP (Fermentas, St Leon-Rot, Germany). The primer sequences are available on request. The PCR for all targets was performed as follows: initial denaturation at $95^{\circ} \mathrm{C}$ for $300 \mathrm{~s}, 33$ cycles with $95^{\circ} \mathrm{C}$ for $60 \mathrm{~s}$, $55^{\circ} \mathrm{C}$ for $45 \mathrm{~s}, 72^{\circ} \mathrm{C}$ for $60 \mathrm{~s}$ and a final elongation step at $72{ }^{\circ} \mathrm{C}$ for $420 \mathrm{~s}$.

\section{Determination of interleukin-6 (IL-6) concentrations}

IL-6 concentrations were determined using the RayBio Mouse IL-6 ELISA Kit (RayBiotech, Norcross, GA, USA) according to the manufacturer's manual.

\section{Oil red O staining}

Tissue culture plates were washed with PBS twice and fixed with $10 \%$ formalin for at least $15 \mathrm{~min}$ at room temperature. Cells were then stained for $1 \mathrm{~h}$ at room temperature with a filtered oil red $\mathrm{O}$ solution (stock solution: $0.5 \mathrm{~g}$ oil red $\mathrm{O}$ in $100 \mathrm{ml}$ isopropyl alcohol, working solution: $60 \%(\mathrm{v} / \mathrm{v})$ stock solution and $\left.40 \%(\mathrm{v} / \mathrm{v}) \mathrm{H}_{2} \mathrm{O}\right)$. The staining solution was washed off the cells with distilled water twice. For densitometry, oil red $\mathrm{O}$ stain was eluted with isopropanol and subjected to photometric analysis at $500 \mathrm{~nm}$. 


\section{Genomic DNA isolation}

Genomic DNA was isolated from pre-adipocytes using the NucleoSpin Tissue kit (Macherey-Nagel, Düren, Germany) according to the manufacturer's instructions.

\section{Glucose uptake}

The cells were assayed for glucose uptake essentially as described previously (Klein et al. 1999, Fasshauer et al. 2000). After a serum-free starvation period of $24 \mathrm{~h}$, fully differentiated monolayers of adipocytes were treated with ACTH $(100 \mathrm{nM})$ for various periods of time and then with insulin $(100 \mathrm{nM})$ for $30 \mathrm{~min}$. At the end of the stimulation period, cells were exposed to 2-deoxy-[3H]-D-glucose $(0.5 \mu \mathrm{Ci} / \mathrm{ml}$ final concentration) for $4 \mathrm{~min}$, and the incorporated radioactivity was determined by liquid scintillation counting.

\section{Statistical analysis}

Data are presented as mean \pm s.D. 'Sigma Stat'-software (SPSS Science, Chicago, IL, USA) was employed for statistical analysis of all data. Statistical significance was determined using the unpaired student's $t$-test. The values of $P<0 \cdot 05$ were considered significant, those $<0 \cdot 01$ highly significant.

\section{Results}

MC 2 and 5 receptors are expressed in adipocytes and are up-regulated during adipogenesis

MC 2 and 5 receptors were expressed in both the white and brown adipocytes. By contrast, $\mathrm{MC} 1,3$ and 4 receptors were not detected at the mRNA level (Fig. 1A).

Protein analysis revealed MC 2 and 5 receptors in white as well as brown adipocytes, but not 1, 3 and 4 receptors (data not shown). Both receptors were up-regulated during adipocyte differentiation (Fig. 1B).

\section{ACTH does not alter differentiation of adipocytes}

The up-regulation of $\mathrm{MC}$ receptors during adipocyte differentiation prompted us to investigate a possible effect of ACTH on adipogenesis and lipid accumulation. Chronic stimulation of white pre-adipocytes with ACTH during a differentiation period of 6 days did not affect lipid accumulation, as determined microscopically and by oil red $O$ staining with subsequent densitometric evaluation (Fig. 2A). Differentiation markers were also evaluated; PPAR $\gamma$ mRNA and aP2 protein concentrations did not differ significantly between chronically ACTH-treated and control cells (Fig. 2B).

\section{ACTH acutely and transiently induces insulin resistance}

Insulin sensitivity is a hallmark of mature adipocytes. Experiments with mature white adipocytes demonstrated a
A

A

White adipocytes
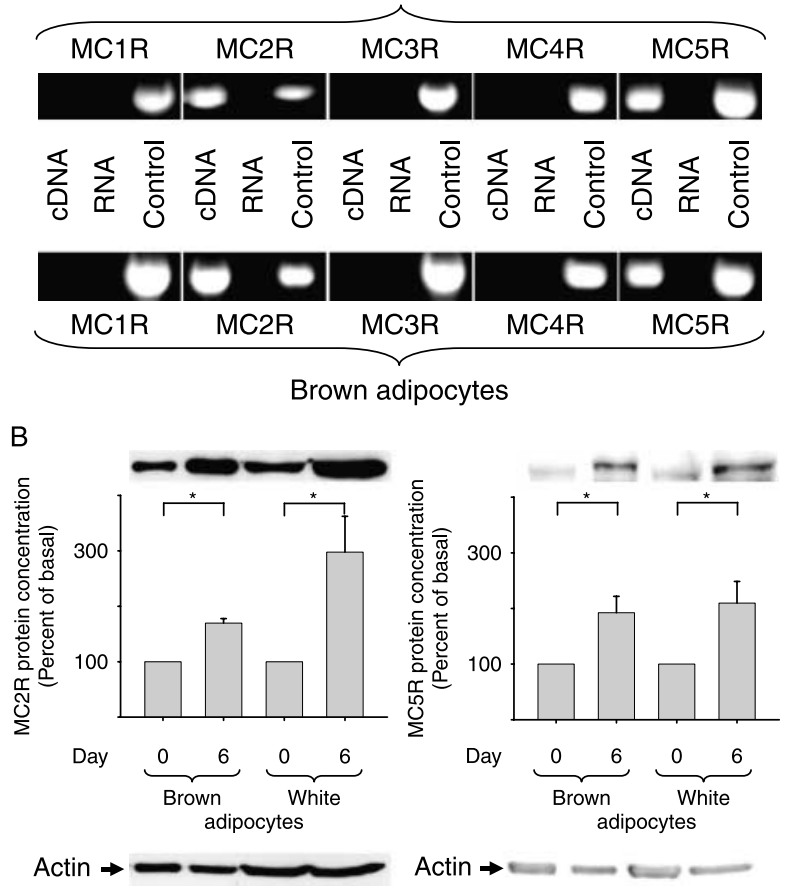

Figure 1 Melanocortin 2 and 5 receptors are expressed in white and brown adipocytes. (A) RNA was isolated from mature white and brown adipocytes, qualitative RT-PCR was performed as described in Materials and Methods ('CDNA' lane). RNA ('RNA' lane) and genomic DNA ('control' lane) were used as templates to serve as negative and positive controls respectively. (B) White and brown pre-adipocytes and mature adipocytes after 6 days of differentiation were investigated. Cell lysates and immunoblots using specific antibodies were prepared as described in Materials and Methods. A bar graph analysis of 3 (MC2R) and $\geq 4$ (MC5R) independent experiments as well as representative immunoblots is shown. Actin served as loading control. MC1 through 5R denotes melanocortin 1 through 5 receptor respectively.

transient reduction in insulin-induced glucose uptake by $45 \%$ after ACTH treatment for $1 \mathrm{~h}(P<0 \cdot 01)$. This negative effect subsided after another $3 \mathrm{~h}$ (Fig. 3). ACTH treatment for $1 \mathrm{~h}$ alone increased glucose uptake by $60 \%(P<0 \cdot 05)$, when compared with untreated cells (Fig. 3).

\section{ACTH induces a pro-inflammatory adipokine expression profile}

Adipose insulin resistance is closely associated with endocrine dysfunction. We next examined direct effects of ACTH on pro-inflammatory and glucose-regulatory hormones in mature white adipocytes.

Visfatin gene expression was reduced by $50 \%$ after $4 \mathrm{~h}$ of ACTH stimulation $(P<0 \cdot 01)$. This effect lasted for another $4 \mathrm{~h}$ (Fig. 4A). Adiponectin mRNA concentrations displayed a similar pattern, ACTH significantly decreased adiponectin mRNA levels by $22 \%$ after treatment for $2 \mathrm{~h}(P<0 \cdot 05)$. This suppression reached a maximum at $8 \mathrm{~h}$ with a reduction of 40\% (P<0.001; Fig. 4B). 


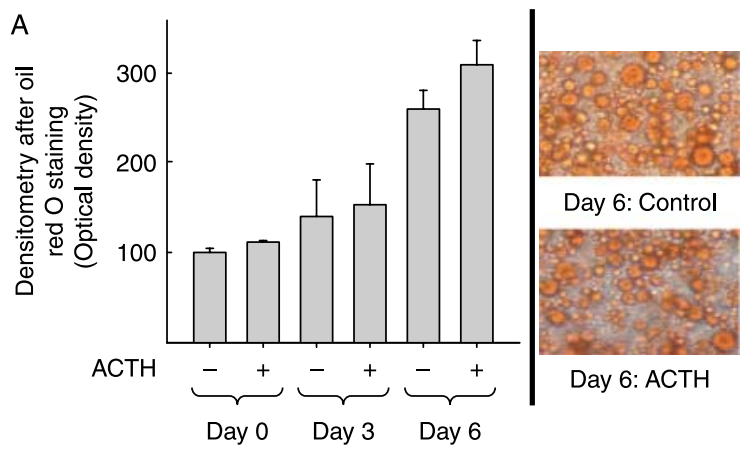

B
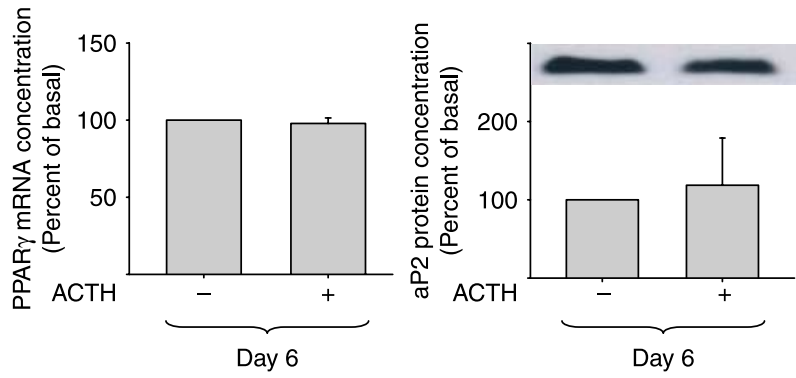

Actin

Figure 2 ACTH does not alter differentiation of adipocytes. White pre-adipocytes were chronically stimulated with ACTH over a period of 6 days during differentiation. (A) Oil red $O$ staining with subsequent densitometric evaluation was performed as described in Materials and Methods. A bar graph analysis of three independent experiments and representative microscopic pictures is shown. (B) PPAR $\gamma$ mRNA quantification was analysed as described in Materials and Methods. A bar graph analysis of three independent experiments is shown. Cell lysates and immunoblots using a specific aP2 antibody were prepared as described in Materials and Methods. A bar graph analysis of three independent experiments and a representative immunoblot is shown. Actin served as loading control.

By contrast, pro-inflammatory adipokines monocyte chemoattractant protein-1 (MCP-1) and IL-6 were up-regulated by ACTH treatment. MCP-1 gene expression maximally increased by $60 \%$ after $30 \mathrm{~min}$ of stimulation with ACTH $(P<0 \cdot 01)$ and returned to basal level after $2 \mathrm{~h}$ (Fig. 4C). IL-6 mRNA concentrations were acutely increased by $2100 \%$ after $30 \mathrm{~min}(P<0 \cdot 01)$ and returned to basal concentrations after $4 \mathrm{~h}$ of ACTH treatment (Fig. 4D). This strong rise was paralleled by an increased secretion of IL-6. The IL-6 protein concentrations in the cell culture medium were elevated by $270 \%$ after $2 \mathrm{~h}$ of ACTH stimulation $(P<0 \cdot 01)$ and reached a maximal increase in $1450 \%$ after $4 \mathrm{~h}$ (Fig. 4E).

\section{ACTH stimulation increases UCP-1 mRNA in brown adipocytes}

The thermogenic brown adipose tissue contributes to energy balance in small mammals and may be associated with insulin sensitivity in human adults (Yang et al. 2003).

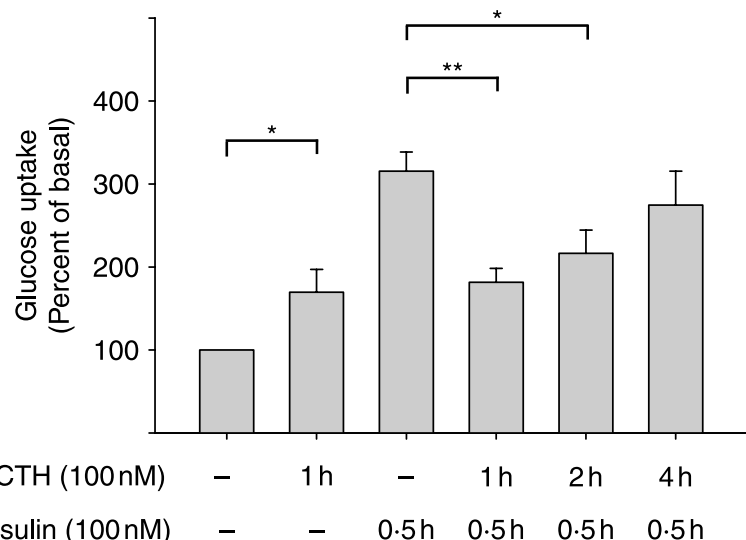

Figure $3 \mathrm{ACTH}$ causes transient insulin resistance in white adipocytes. White adipocytes were stimulated with ACTH for the times indicated. Insulin-induced glucose uptake was determined as described in Materials and Methods. A bar graph analysis of $\geq 6$ independent experiments is shown. ${ }^{*} P<0 \cdot 05,{ }^{* *} P<0 \cdot 01$.

Exposure of brown adipocytes to ACTH significantly increased UCP-1 protein concentrations by $170 \%$ after $8 \mathrm{~h}$ $(P<0 \cdot 01)$ and maximally by $470 \%$ after $24 \mathrm{~h}(P<0 \cdot 05$; Fig. 5B). This effect was preceded by a transient, maximally $690 \%$ rise in UCP-1 mRNA levels between 1 and $8 \mathrm{~h}$ of ACTH treatment $(P<0 \cdot 01$; Fig. $5 \mathrm{~A})$.

\section{p38 MAPK mediates UCP-1 induction by ACTH}

p38 MAPK pathways have been reported to mediate UCP-1 gene regulation. Using a phospho-specific antibody, an increase in p38 MAPK phosphorylation by $1800 \%$ was detectable after $10 \mathrm{~min}$ of ACTH treatment $(P<0 \cdot 05$; Fig. 6A). Total p38 MAPK content of the cells remained unchanged during this period (Fig. 6A, insert). The ACTH treatment of brown adipocytes for $24 \mathrm{~h}$ caused an increase in UCP-1 protein concentrations again, which was abolished by SB 202190, a selective inhibitor of p38 MAPK $(P<0 \cdot 01$; Fig. 6B).

By contrast, pharmacological inhibition of phosphatidylinositol 3-kinase (LY 294002) and p44/p42 MAPK (PD 98059) did not affect the ACTH-induced rise in UCP-1 mRNA concentrations (data not shown).

\section{Discussion}

Our study demonstrates direct multi-level crosstalk of ACTH with key metabolic and endocrine functions of white and brown adipocytes. ACTH induces a transient insulin resistance, a pro-inflammatory adipokine expression profile and a p38 MAPK-mediated increase in UCP-1.

To our knowledge, this study is the first to profile $\mathrm{MC}$ receptor expression at the protein level. We find MC 2 and 5 receptors, but not 1, 3 and 4 receptors. Our findings are in accordance with previous reports on MC receptor mRNA 


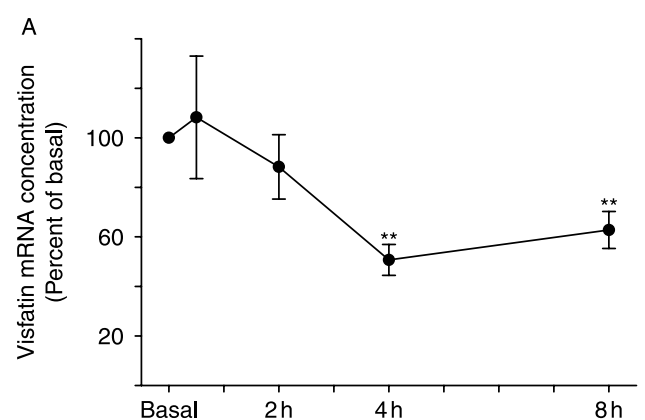

B
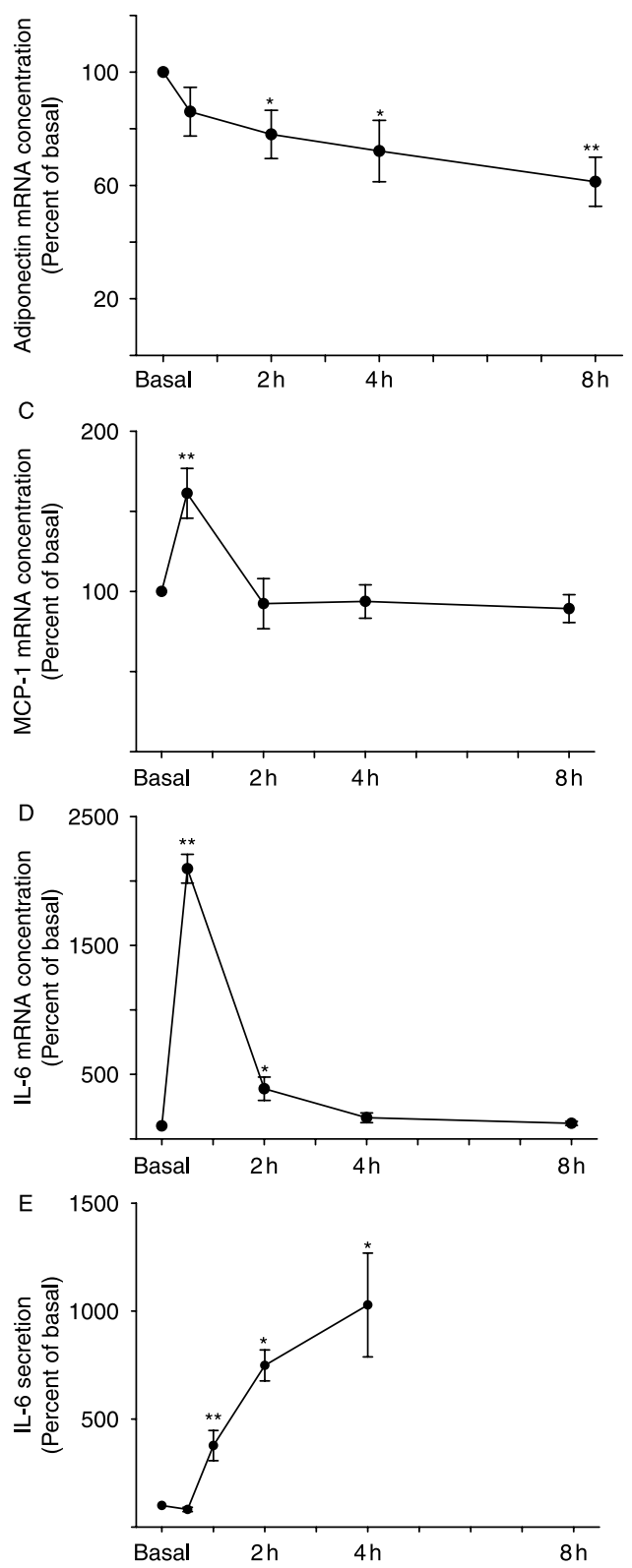

expression in murine adipose cells (Boston \& Cone 1996, Norman et al. 2003). The observed up-regulation of the receptors during differentiation raised the question of an involvement of ACTH in this process. An inhibition of differentiation and adipogenesis of murine pre-adipocytes in the presence of $\alpha \mathrm{MSH}$ has previously been reported (Smith et al. 2003). In our study, ACTH did not significantly alter adipogenesis of white adipocytes. This may be due to differences in receptor affinities of $\alpha \mathrm{MSH}$ and ACTH: $\mathrm{ACTH}$ binds to both receptors, whereas $\alpha \mathrm{MSH}$ only binds to MC5R.

Insulin resistance is a key component of the metabolic syndrome and its complications. ACTH caused transient insulin resistance as demonstrated by a decrease in insulininduced glucose uptake. In vivo, this short-term effect may facilitate an increased availability of glucose to other tissues such as the brain and muscle in physiologically stressful states. An increase in total body energy demand might further be met by previously reported increases in lipolysis mediated by MCs in rodents, in vivo as well as in vitro (White \& Engel 1958, Cho et al. 2005).

ACTH stimulation appears to induce a pro-inflammatory adipocyte response. Adiponectin and visfatin have been reported to ameliorate insulin resistance in vivo, and their expression is reduced in subjects with insulin resistance (Fasshauer \& Paschke 2003, Hug \& Lodish 2005, Klein et al. 2006). Our study provides evidence for an acute decrease in the expression of both adipokines, which could contribute to an overall insulin-resistant state.

By contrast, the pro-inflammatory adipokines IL-6 and MCP-1 are acutely increased by ACTH at the mRNA level. The elevation of IL-6 gene expression is paralleled by an increased IL-6 protein secretion. Effects of IL-6 are complex and appear to be time and tissue specific. Of note, IL-6 production in muscle fibres is increased by exercise, and IL-6 might act as a myocyte-derived 'exercise factor' that increases energy supply for the muscle by enhancing myocyte glucose uptake and $\beta$-oxidation of fatty acids (Al-Khalili et al. 2006, Weigert et al. 2006). The IL-6 secretion of adipocytes in states of acute stress might contribute to these effects. On the other hand, chronically increased IL-6 concentrations correlate with an overall insulin-resistant state (Fernandez-Real \& Ricart 2003). Elevated MCP-1 levels are also associated with insulin resistance and an inflammatory state (Sartipy \& Loskutoff 2003, Kamei et al. 2006, Kanda et al. 2006, Sell et al. 2006, Shoelson et al. 2006). Taken together, ACTH

Figure 4 ACTH stimulation of white adipocytes causes a proinflammatory adipokine profile. White adipocytes were stimulated with ACTH for the times indicated. (A-D) mRNA quantification of adipokines in white adipocytes were analysed as described in Materials and Methods. Bar graph analyses of four independent experiments are shown. (E) IL-6 concentrations in the cell culture supernatant of white adipocytes were determined as described in Materials and Methods. A bar graph analysis of four independent experiments is shown. ${ }^{*} P<0 \cdot 05, * * P<0 \cdot 01$. 


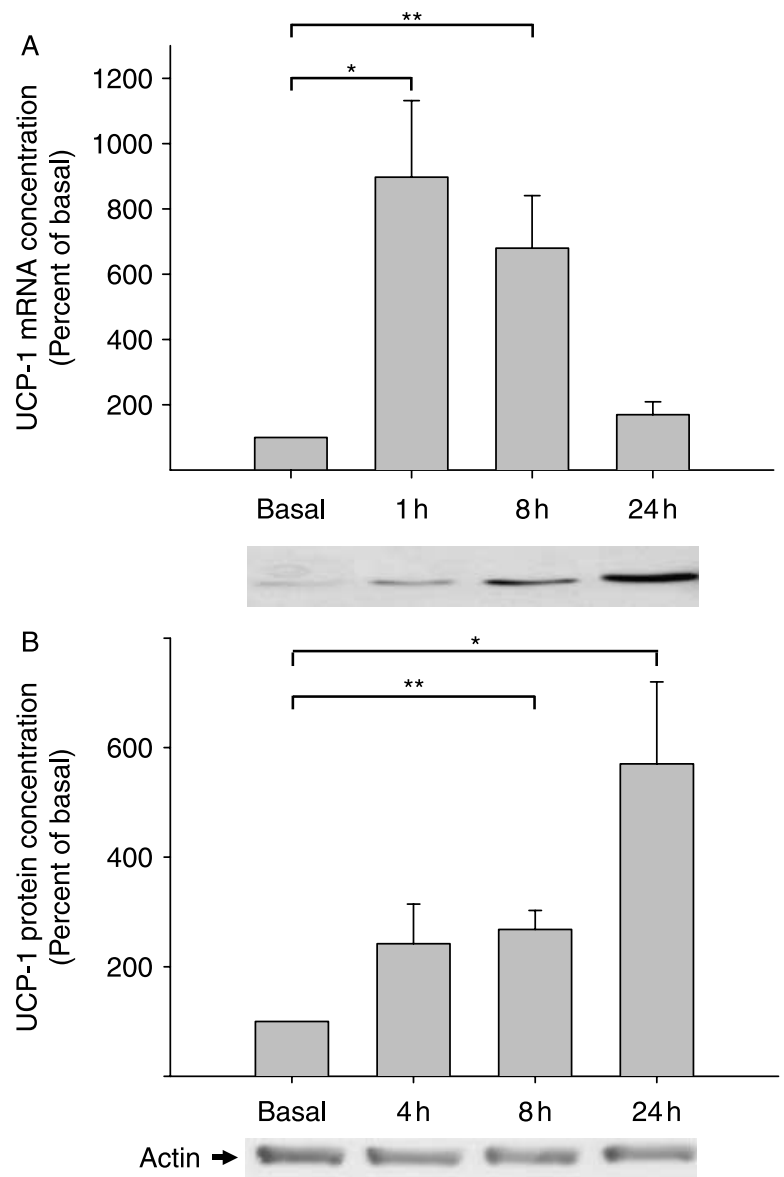

Figure 5 Up-regulation of UCP-1 in brown adipocytes caused by ACTH. Brown adipocytes were stimulated with ACTH for the times indicated. (A) UCP-1 mRNA quantification was analysed as described in Materials and Methods. A bar graph analysis of five independent experiments is shown. (B) Cell lysates and immunoblots using a specific antibody were prepared as described in Materials and Methods. A bar graph analysis of five independent experiments and a representative immunoblot is shown. Actin served as loading control. ${ }^{*} P<0 \cdot 05,{ }^{* *} P<0 \cdot 01$.

induces an adipokine profile that is associated with insulin resistance and inflammation.

Thermogenesis is mediated by UCP- 1 in brown adipocytes and contributes to energy expenditure. Centrally administered MCs are known to increase energy expenditure and UCP-1 gene expression in brown adipocytes of rodents (Pierroz et al. 2002, Williams et al. 2003, Li et al. 2004). This effect is thought to be indirectly mediated via the sympathetic nervous system (Voss-Andreae et al. 2007). We report evidence for a direct induction of UCP-1 gene expression by MCs. This provides a complementary direct mechanism of ACTH action. This finding is further supported by a previous report; peripheral administration of a MC receptor agonist to food-restricted rats prevented the typically observed decrease in UCP-1 (Cettour-Rose \& Rohner-Jeanrenaud 2002).

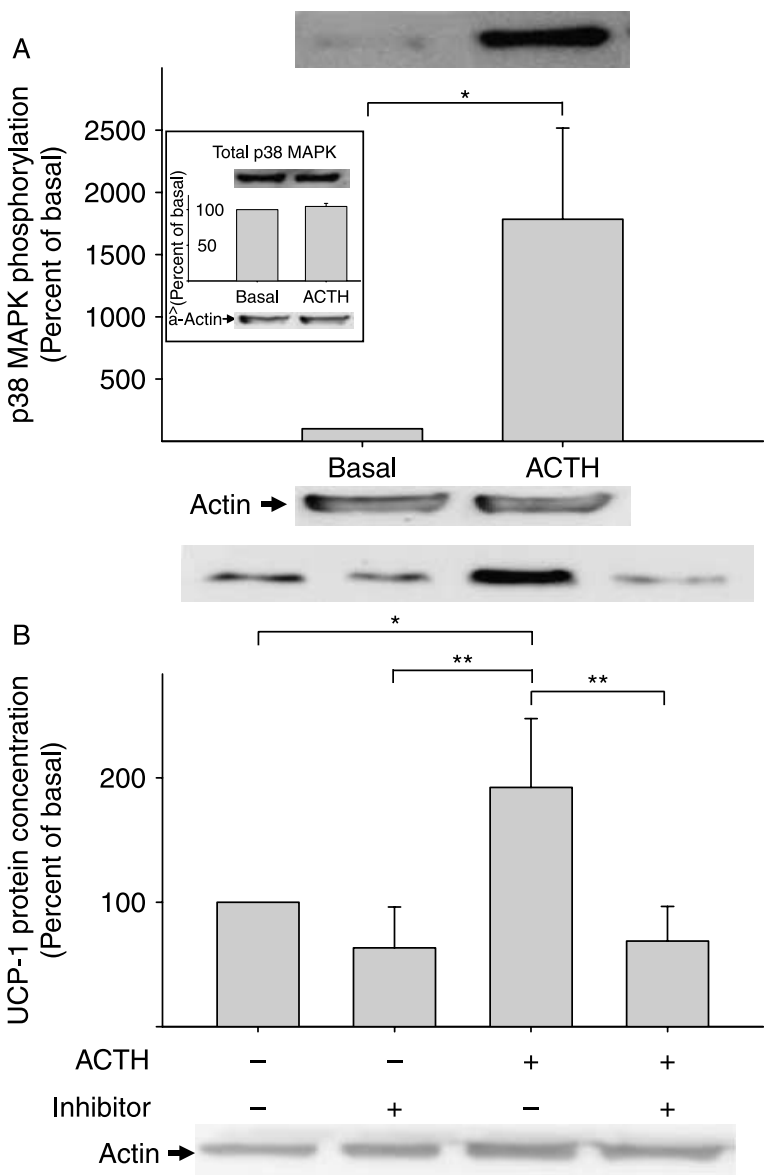

Figure 6 Involvement of p38 MAPK in regulation of UCP-1 protein concentration by ACTH. (A) Brown adipocytes were stimulated with $\mathrm{ACTH}$ for $10 \mathrm{~min}$. Cell lysates and immunoblots using specific antibodies were prepared as described in Materials and Methods. p38 MAPK phosphorylation: A bar graph analysis of eight independent experiments with S.E.M. and a representative immunoblot is shown. Total p38 MAPK: A bar graph analysis of four independent experiments and a representative immunoblot is shown. (B) Brown adipocytes were stimulated with ACTH for $24 \mathrm{~h}$ with or without the specific p38 MAPK inhibitor SB 202190 was added $1 \mathrm{~h}$ prior to ACTH. UCP-1 protein was analysed as described in Materials and Methods. A bar graph analysis including the S.E.M. of four independent experiments and a representative immunoblot is shown. ${ }^{*} P<0 \cdot 05,{ }^{* *} P<0 \cdot 01$. Actin served as loading control.

The direct effect of ACTH on the up-regulation of UCP-1 gene activity is mediated by p38 MAPK. ACTH not only increased p 38 MAPK phosphorylation by $1800 \%$, but specific inhibition of $\mathrm{p} 38$ MAPK also abolished the ACTH-mediated elevation of UCP-1 protein concentration. These findings are in accordance with previous reports on UCP-1 activation (Valladares et al. 2001, Teruel et al. 2003, Cao et al. 2004). Furthermore, PI 3-K and p44/p42 MAPK do not seem to play a role in the ACTH-mediated UCP-1 gene up-regulation, since pharmacological inhibition of these kinases did not affect the ACTH-induced rise of UCP-1 mRNA concentrations. 
Taken together, our data provide evidence for direct multilevel effects of ACTH on adipose insulin sensitivity, endocrine function and thermogenesis. This direct crosstalk promotes an insulin-resistant, pro-inflammatory state and transiently enhances energy combustion. In a wider context, these findings provide evidence for direct effects of neuroendocrine peptides on key adipose functions. Direct adipotropic actions of neuropeptides thereby contribute to adipose dysregulation and associated metabolic and cardiovascular disease.

\section{Acknowledgements}

$\mathrm{J} \mathrm{K}$ is a Feodor-Lynen Fellow of the Humboldt Foundation. This study was supported by grants from the Deutsche Forschungsgemeinschaft (Kl 1131/2-5 to J K). The authors state no conflict of interest.

\section{References}

Al-Khalili L, Bouzakri K, Glund S, Lonnqvist F, Koistinen HA \& Krook A 2006 Signaling specificity of interleukin-6 action on glucose and lipid metabolism in skeletal muscle. Molecular Endocrinology 20 3364-3375.

Boston BA 1999 The role of melanocortins in adipocyte function. Annals of the New York Academy of Sciences 885 75-84.

Boston BA \& Cone R 1996 Characterization of melanocortin receptor subtype expression in murine adipose tissues and in the 3T3-L1 cell line. Endocrinology 137 2043-2050.

Butler AA 2006 The melanocortin system and energy balance. Peptides $\mathbf{2 7}$ 281-290.

Cao W, Daniel KW, Robidoux J, Puigserver P, Medvedev AV, Bai X, Floering LM, Spiegelman BM \& Collins S 2004 p38 Mitogen-activated protein kinase is the central regulator of cyclic AMP-dependent transcription of the brown fat uncoupling protein 1 gene. Molecular and Cellular Biology 24 3057-3067.

Cettour-Rose P \& Rohner-Jeanrenaud F 2002 The leptin-like effects of 3-d peripheral administration of a melanocortin agonist are more marked in genetically obese Zucker (fa/fa) than in lean rats. Endocrinology 143 22772283.

Cho K-J, Shim J-H, Cho M-C, Choe Y-K, Hong J-T, Moon D-C, Kim J-W \& Yoon D-Y 2005 Signaling pathways implicated in alpha-melanocyte stimulating hormone-induced lipolysis in 3T3-L1 adipocytes. Journal of Cellular Biochemistry 96 869-878.

Despres J-P \& Lemieux I 2006 Abdominal obesity and metabolic syndrome. Nature 444 881-887.

Farooqi IS \& O'Rahilly S 2006 Genetics of obesity in humans. Endocrine Reviews 27 710-718.

Fasshauer M \& Paschke R 2003 Regulation of adipocytokines and insulin resistance. Diabetologia 46 1594-1603.

Fasshauer M, Klein J, Ueki K, Kriauciunas KM, Benito M, White MF \& Kahn CR 2000 Essential role of insulin receptor substrate-2 in insulin stimulation of Glut4 translocation and glucose uptake in brown adipocytes. Journal of Biological Chemistry 275 25494-25501.

Fernandez-Real JM \& Ricart W 2003 Insulin resistance and chronic cardiovascular inflammatory syndrome. Endocrine Reviews 24 278-301.

Gantz I \& Fong TM 2003 The melanocortin system. American Journal of Physiology. Endocrinology and Metabolism 284 E468-E474.

Hoggard N, Hunter L, Duncan J \& Rayner D 2004 Regulation of adipose tissue leptin secretion by alpha-melanocyte-stimulating hormone and agouti-related protein: further evidence of an interaction between leptin and the melanocortin signalling system. Journal of Molecular Endocrinology $32145-153$
Hug C \& Lodish HF 2005 The role of the adipocyte hormone adiponectin in cardiovascular disease. Current Opinion in Pharmacology 5 129-134.

Jost P, Fasshauer M, Kahn CR, Benito M, Meyer M, Ott V, Lowell BB, Klein HH \& Klein J 2002 A typical beta-adrenergic effects on insulin signaling and action in beta 3 -adrenoceptor-deficient brown adipocytes. American Journal of Physiology. Endocrinology and Metabolism 283 E146-E153.

Kamei N, Tobe K, Suzuki R, Ohsugi M, Watanabe T, Kubota N, OhtsukaKowatari N, Kumagai K, Sakamoto K, Kobayashi M et al. 2006 Overexpression of monocyte chemoattractant protein-1 in adipose tissues causes macrophage recruitment and insulin resistance. Journal of Biological Chemistry 281 26602-26614.

Kanda H, Tateya S, Tamori Y, Kotani K, Hiasa K-I, Kitazawa R, Kitazawa S, Miyachi H, Maeda S, Egashira K et al. 2006 MCP-1 contributes to macrophage infiltration into adipose tissue, insulin resistance, and hepatic steatosis in obesity. Journal of Clinical Investigation 116 1494-1505.

Klein J, Fasshauer M, Ito M, Lowell BB, Benito M \& Kahn CR 1999 $\beta 3$-Adrenergic stimulation differentially inhibits insulin signaling and decreases insulin-induced glucose uptake in brown adipocytes. Journal of Biological Chemistry 274 34795-34802.

Klein J, Fasshauer M, Benito M \& Kahn CR 2000 Insulin and the beta3-adrenoceptor differentially regulate uncoupling protein-1 expression. Molecular Endocrinology 14 764-773.

Klein J, Fasshauer M, Klein HH, Benito M \& Kahn CR 2002 Novel adipocyte lines from brown fat: a model system for the study of differentiation, energy metabolism, and insulin action. BioEssays 24 382-388.

Klein J, Perwitz N, Kraus D \& Fasshauer M 2006 Adipose tissue as source and target for novel therapies. Trends in Endocrinology and Metabolism 17 26-32.

Kraus D, Fasshauer M, Ott V, Meier B, Jost M, Klein H \& Klein J 2002 Leptin secretion and negative autocrine crosstalk with insulin in brown adipocytes. Journal of Endocrinology 175 185-191.

Li G, Zhang Y, Wilsey J \& Scarpace P 2004 Unabated anorexic and enhanced thermogenic responses to melanotan II in diet-induced obese rats despite reduced melanocortin 3 and 4 receptor expression. Journal of Endocrinology $182123-132$.

Norman D, Isidori AM, Frajese V, Caprio M, Chew SL, Grossman AB, Clark AJ, Besser MG \& Fabbri A 2003 ACTH and (alpha)-MSH inhibit leptin expression and secretion in 3T3-L1 adipocytes: model for a centralperipheral melanocortin-leptin pathway. Molecular and Cellular Endocrinology 200 99-109.

Pasquali R, Cantobelli S, Casimirri F, Capelli M, Bortoluzzi L, Flamia R, Labate A \& Barbara L 1993 The hypothalamic-pituitary-adrenal axis in obese women with different patterns of body fat distribution. Journal of Clinical Endocrinology and Metabolism 77 341-346.

Perwitz N, Fasshauer M \& Klein J 2006 Cannabinoid receptor signaling directly inhibits thermogenesis and alters expression of adiponectin and visfatin. Hormone and Metabolic Research 38 356-358.

Pfaffl MW, Horgan GW \& Dempfle L 2002 Relative expression software tool $(\mathrm{REST}(\mathrm{C}))$ for group-wise comparison and statistical analysis of relative expression results in real-time PCR. Nucleic Acids Research 30 e36.

Pierroz DD, Ziotopoulou M, Ungsunan L, Moschos S, Flier JS \& Mantzoros CS 2002 Effects of acute and chronic administration of the melanocortin agonist MTII in mice with diet-induced obesity. Diabetes 51 1337-1345.

Rosmond R 2003 Stress induced disturbances of the HPA axis: a pathway to type 2 diabetes? Medical Science Monitor 9 RA35-RA39.

Sartipy P \& Loskutoff DJ 2003 Monocyte chemoattractant protein 1 in obesity and insulin resistance. PNAS $1007265-7270$.

Sell H, Dietze-Schroeder D, Kaiser U \& Eckel J 2006 Monocyte chemotactic protein-1 is a potential player in the negative cross-talk between adipose tissue and skeletal muscle. Endocrinology 147 2458-2467.

Shoelson SE, Lee J \& Goldfine AB 2006 Inflammation and insulin resistance. Journal of Clinical Investigation 116 1793-1801.

Smith SR, Gawronska-Kozak B, Janderova L, Nguyen T, Murrell A, Stephens JM \& Mynatt RL 2003 Agouti expression in human adipose tissue: functional consequences and increased expression in type 2 diabetes. Diabetes 52 2914-2922. 
Teruel T, Hernandez R, Benito M \& Lorenzo M 2003 Rosiglitazone and retinoic acid induce uncoupling protein-1 (UCP-1) in a p38 mitogenactivated protein kinase-dependent manner in fetal primary brown adipocytes. Journal of Biological Chemistry 278 263-269.

Valladares A, Roncero C, Benito M \& Porras A 2001 TNF-(alpha) inhibits UCP-1 expression in brown adipocytes via ERKs: opposite effect of p38MAPK. FEBS Letters 493 6-11.

Vicennati V \& Pasquali R 2000 Abnormalities of the hypothalamic-pituitaryadrenal axis in nondepressed women with abdominal obesity and relations with insulin resistance: evidence for a central and a peripheral alteration. Journal of Clinical Endocrinology and Metabolism 85 4093-4098.

Voss-Andreae A, Murphy JG, Ellacott KLJ, Stuart RC, Nillni EA, Cone RD \& Fan W 2007 Role of the central melanocortin circuitry in adaptive thermogenesis of brown adipose tissue. Endocrinology 148 1550-1560.

Weigert C, Hennige AM, Lehmann R, Brodbeck K, Baumgartner F, Schauble M, Haring HU \& Schleicher ED 2006 Direct cross-talk of interleukin-6 and insulin signal transduction via insulin receptor substrate-1 in skeletal muscle cells. Journal of Biological Chemistry 281 7060-7067.
White JE \& Engel FL 1958 Lipolytic action of corticotropin on rat adipose tissue in vitro. Journal of Clinical Investigation 37 1549-1555.

Williams DL, Bowers RR, Bartness TJ, Kaplan JM \& Grill HJ 2003 Brainstem melanocortin $3 / 4$ receptor stimulation increases uncoupling protein gene expression in brown fat. Endocrinology 144 4692-4697.

Yang X, Enerback S \& Smith U 2003 Reduced expression of FOXC2 and brown adipogenic genes in human subjects with insulin resistance. Obesity Research 11 1182-1191.

Received in final form 14 November 2007

Accepted 19 December 2007

Made available online as an Accepted Preprint 19 December 2007 